\title{
Identification of new mutations in the TBX5 gene in patients with Holt-Oram syndrome
}

\author{
W Heinritz, A Moschik, A Kujat, S Spranger, H Heilbronner, S Demuth, A Bier, M Tihanyi, \\ S Mundlos, C Gruenauer-Kloevekorn, U G Froster
}

$\mathrm{H}$ olt-Oram syndrome (HOS) (MIM 142900), first described by Holt and Oram in 1960, is characterised by malformations of the upper limbs involving mainly the pre-axial ray and variable cardiac defects, most of them septation defects. This autosomal dominant inherited condition occurs in approximately 1 in 100000 live births and shows high penetrative and variable intrafamilial and interfamilial clinical expression.

The gene locus for HOS was mapped to chromosome 12q24.1. Mutations in the TBX5 gene (MIM *601620) were delineated as the underlying defect in HOS. ${ }^{1-5}$ TBX5 is a member of the T-box transcription factor family. It plays an indispensable role in development of heart and upper limbs during embryogenesis. To date there have been 34 different mutations at DNA level described in families with HOS; these mutations are spread over all the coding exons of the TBX5 gene. $^{1-5}$

\section{PATIENTS AND METHODS}

The patients for our study were recruited by a circular letter to human geneticists, experts in dysmorphology, and child cardiologists throughout Germany, Austria, Hungary, and Switzerland. The participating colleagues were asked to summarise the clinical data of their patients (all presenting with a combination of variable congenital heart defects and upper limb malformations) in a standardised format. DNA samples of all patients and their first degree relatives were collected after informed consent. Genomic DNA was prepared from peripheral blood according to standard procedures. Primers for analysis of exon 2-9 of the TBX5 gene were designed as published by Basson and colleagues. ${ }^{1}$ The position of nucleotides was identified according to the GenBank sequence U89353.1.

Exons 2-9 of the TBX5 gene were amplified by polymerase chain reaction (PCR) in a $50 \mu \mathrm{l}$ reaction volume containing $200 \mathrm{ng}$ of genomic DNA, $1 \times$ PCR buffer II, $0.2 \mathrm{mM}$ deoxynucleotide triphosphate (dNTP), $2.5 \mathrm{mM} \mathrm{MgCl}_{2}, 1 \mu \mathrm{l}$ of each primer ( $10 \mathrm{pM})$, and $1 \mathrm{U}$ AmpliTaq polymerase (Applera, USA). Cycling program on a GeneAmp PCR System 2400 (PE, USA) was as following: $95^{\circ} \mathrm{C}$ for 2 minutes, 30 cycles of 20 seconds at $95^{\circ} \mathrm{C}, 30$ seconds at $60^{\circ} \mathrm{C}, 45$ seconds at $72^{\circ} \mathrm{C}$, and finally 7 minutes at $72^{\circ} \mathrm{C}$. PCR products were analysed on $1.4 \%$ agarose gels, purified with the Qiaquick PCR purification kit (Qiagen, Germany), cycle sequenced by using the BigDye-DNA sequencing kit (Applera, USA), and analysed on an ABI Prism 377 DNA sequencer (PE, USA) according to the protocol of the manufacturer.

\section{RESULTS}

Among a total of 42 unrelated patients we found mutations in the TBX5 gene in nine patients $(22 \%)$, four familial and five sporadic cases of HOS. The results of mutation analysis and the clinical data of the patients and their affected relatives are summarised in table 1.
The spectrum of identified pathogenic sequence variations includes three frameshift mutations and one nonsense mutation, which are predicted to lead to a truncated gene product causing HOS in the mutation carrier. Furthermore, we found one well known nonsense mutation (R279X) and one mutation, which could be detected in two unrelated families (Y136X). The last one was recently published as a special case report. ${ }^{4}$ Consanguinity between all families was excluded by extensive pedigree analyses. In two other patients new splice site mutations have been identified. The effects of these mutations are yet unknown, but they are suggested to cause HOS.

The mutational change in all cases was associated with different skeletal and heart anomalies (table 1). Carriers of mutations leading to a premature translational stop showed a severe phenotype of HOS. Patients IPM 1 and IPM 7, which carry the splice site mutations, showed a milder phenotype with only thumb anomalies and conductive heart failure and small atrial septal defects and ventricular septal defects respectively.

\section{DISCUSSION}

Mutations in the TBX5 gene spread over the entire coding region. Most of them are located within the highly conserved DNA binding T-box domain of the gene, spanning from amino acids 55-237. It was shown that the amino acids 1-54, which are not fully conserved, as well as the C-terminal residues $238-518$ in the TBX5 protein, are required for effective DNA binding and regulation. This finding was reinforced by identification of mutations in these parts of the TBX5 gene in HOS patients. ${ }^{2}$

The mutation R279X can be suggested as a hot spot mutation in the TBX5 gene. In our study patient IPM 8, with a severe clinical manifestation of HOS, is a carrier of R279X. Altogether just five of all presently known mutations in TBX5 (S196X, T223M, R237Q, R237W, R279X) are responsible for about $50 \%$ of all cases of HOS.

Notably there is no evidence for a special genotype/ phenotype correlation of nonsense or frameshift mutations within or outside the T-box domain. ${ }^{2}$ In contrast to this, a distinct mechanism of missense mutation effects in TBX5 was suggested. The position of missense mutations within the $\mathrm{T}$ box domain seems to be associated with phenotype expressions showing either predominantly heart defects (G80R,G169R) or limb anomalies (R237Q, R237W). ${ }^{13}$ To date 11 different missense mutations in TBX5 are known. In our study no missense mutations were detected.

The mutation in patient IPM 1 alters a highly conserved nucleotide at the $3^{\prime}$ acceptor splice site of intron 3. In most eukaryotic genes an adenine is located at position two of the $3^{\prime}$ intronic site. This mutation was not detectable in 50 control samples. Therefore, it can be presumed that the mutation produces an alternatively spliced protein which causes HOS in our patient. 
Table 1 Clinical data of HOS patients with an identified mutation in the TBX5 gene

\begin{tabular}{|c|c|c|c|c|c|}
\hline \multirow[b]{2}{*}{ ID number } & \multirow{2}{*}{$\begin{array}{l}\text { Age } \\
\text { (years) }\end{array}$} & \multirow[b]{2}{*}{ Sex } & \multicolumn{2}{|l|}{ Clinical description } & \multirow[b]{2}{*}{ Mutation in TBX5 } \\
\hline & & & Heart anomalies & Limb anomalies & \\
\hline \multicolumn{6}{|l|}{ Familial cases } \\
\hline IPM 1 & 31 & $\mathrm{~F}$ & Conductive heart failure & Left and right thumb anomaly & IVS3-2 A>G \\
\hline IPM 2-1 & 14 & $\mathrm{~F}$ & Ventricular septal defect & Left aplastic thumb, right triphalangeal thumb & 280delC $>$ FS ter \\
\hline IPM 2-2 & 16 & $\mathrm{~F}$ & $\begin{array}{l}\text { Atrial septal defect II, several } \\
\text { ventricular septal defects }\end{array}$ & $\begin{array}{l}\text { Left and right hypoplastic claviculae, radii } \\
\text { triphalangeal thumbs, hypoplastic left ulna }\end{array}$ & 280delC $>$ FS ter \\
\hline IPM 2-3 & 42 & $\mathrm{~F}$ & Ventricular septal defect & Left and right triphalangeal thumbs & 280delC $>$ FS ter \\
\hline IPM 3-1 & 21 & $\mathrm{~F}$ & $\begin{array}{l}\text { Atrial septal defect II, open } \\
\text { foramen ovale }\end{array}$ & Left and right hypoplastic thumbs & Y136X \\
\hline IPM 3-2 & 44 & $\mathrm{~F}$ & Atrial septal defect & $\begin{array}{l}\text { Hypoplastic thumbs, movement restriction of } \\
\text { elbow and shoulder joints }\end{array}$ & Y136X \\
\hline IPM 3-3 & 47 & M & Atrial septal defect & Left and right hypoplastic thumbs & Y136X \\
\hline IPM 4-1 & 42 & M & Atrial septal defect & Left and right hypoplastic humeri & Y136X \\
\hline IPM 4-2 & 58 & M & Atrial septal defect & $\begin{array}{l}\text { Left hypoplastic } M \text {. deltoideus, radius and } \\
\text { thumb, right triphalangeal thumb }\end{array}$ & Y136X \\
\hline $\begin{array}{l}\text { IPM 4-3 } \\
\text { Sporadic cases }\end{array}$ & 61 & M & Atrial septal defect & Left and right aplastic thumbs & Y136X \\
\hline IPM 5 & 23 & $\mathrm{~F}$ & Atrial septal defect II & Left and right thumb anomalies & 467 ins $A>F S$ ter \\
\hline IPM 6 & 30 & $\mathrm{~F}$ & $\begin{array}{l}\text { Aneurysm of the atrial septum } \\
\text { bradycardia }\end{array}$ & $\begin{array}{l}\text { Left aplastic radius and ulna, hypoplastic } \\
\text { humerus, aplastic thumb and index finger, } \\
\text { right hypoplastic radius, aplastic index } \\
\text { finger, triphalangeal thumb }\end{array}$ & 484 ins $46 b p>F S$ ter \\
\hline IPM 7 & 3 & $\mathrm{~F}$ & $\begin{array}{l}\text { Small atrial septal defect, } \\
\text { ventricular septal defect }\end{array}$ & Left and right thumb anomalies & IVS7-3 C>G \\
\hline IPM 8 & 31 & $\mathrm{~F}$ & $\begin{array}{l}\text { Common atrium, } \\
\text { complete atrioventricular canal }\end{array}$ & $\begin{array}{l}\text { Left phocomelia, hypoplastic radius, } \\
\text { right hypoplastic thumb }\end{array}$ & $\mathrm{R} 279 \mathrm{X}$ \\
\hline IPM 9 & 14 & $\mathrm{~F}$ & $\begin{array}{l}\text { Atrial septal defect, ventricular } \\
\text { septal defect, pulmonary vein } \\
\text { anomaly }\end{array}$ & $\begin{array}{l}\text { Left and right triphalangeal thumb, movement } \\
\text { restriction of shoulder joints }\end{array}$ & Q362X \\
\hline
\end{tabular}

For patient IPM 7, who is carrier of the mutation IVS7-3 $\mathrm{C}>\mathrm{G}$, we compared sequences of the TBX5 gene of various species and have found partial consent at the $3^{\prime}$ acceptor splice site of intron 7-for example in Mus musculus (NCBI, Acc.-No: NT 039312). The mutation seems to be responsible for HOS in this patient because it was not found in 50 control samples including both parents of IPM 7.

In HOS patients without mutations in TBX5 further investigations should comprehend proper methods to exclude gross deletions within the gene or chromosomal changes. The overall mutation detection rate in our cohort was as low as in other studies $(22 \%)$. Reasons, such as clinical misdiagnosis, genetic heterogeneity of HOS, and mutations outside the TBX5 gene have to be considered. Investigation of other genes, which are primarily associated with congenital heart and limb defects-for example SALL4-may help to distinguish similarly appearing phenotypes. ${ }^{2}$

\section{Authors' affiliations}

W Heinritz, A Moschik, A Kujat, U G Froster, Institute of Human Genetics, University of Leipzig Medical Faculty, Leipzig, Germany S Spranger, Private Practice of Human Genetics, Bremen, Germany H Heilbronner, Institute of Clinical Genetics, Olgahospital, Stuttgart, Germany

S Demuth, Private Practice of Human Genetics, Erfurt, Germany
A Bier, Institute of Clinical Genetics, Universitätsklinikum Carl-GustavCarus, University of Technology, Dresden, Germany

M Tihanyi, Zala County Hospital, Department of Human Genetics, Zalaegerszeg, Hungary

S Mundlos, Institute of Medical Genetics, Charité, Campus Virchow, Berlin, Germany

C Gruenauer-Kloevekorn, Department of Ophthalmology, MartinLuther-University Halle-Wittenberg, Halle, Germany

Correspondence to: Professor Dr Med Ursula G Froster, Institute of Human Genetics, University of Leipzig Medical Faculty, PhilippRosenthal-Str. 55, 04103 Leipzig, Germany;

frou@medizin.uni-leipzig.de

Accepted 19 May 2004

\section{REFERENCES}

1 Basson CT, Bachinsky DR, Lin RC, et al. Mutations in human TBX5 [corrected] cause limb and cardiac malformation in Holt-Oram syndrome. Nat Genet 1997;15(1):30-5.

2 Brassington AME, Sung SS, Toydemir RM, et al. Expressivity of Holt-Oram syndrome is not predicted by TBX5 genotype. Am J Hum Genet 2003;73:74-85.

3 Cross SJ, Ching YH, Li QY, et al. The mutation spectrum in Holt-Oram syndrome. J Med Genet 2000;37:785-7.

4 Gruenauer-Kloevekorn C, Froster UG. Holt-Oram syndrome: a new mutation in the TBX5 gene in two unrelated families. Ann Genet 2003;46:19-23.

5 Li QY, Newbury-Ecob RA, Terrett JA, et al. Holt-Oram syndrome is caused by mutations in TBX5, a member of the Brachyury (T) gene family. Nat Genet 1997; 15:21-9. 